\title{
Author Correction: Prefrontal cortical ChAT-VIP interneurons provide local excitation by cholinergic synaptic transmission and control attention
}

\author{
Joshua Obermayer, Antonio Luchicchi, Tim S. Heistek, Sybren F. de Kloet, Huub Terra, Bastiaan Bruinsma, \\ Ouissame Mnie-Filali, Christian Kortleven, Anna A. Galakhova (D, Ayoub J. Khalil, Tim Kroon (D, Allert J. Jonker, \\ Roel de Haan (1), Wilma D.J. van de Berg (D), Natalia A. Goriounova (1), Christiaan P.J. de Kock, Tommy Pattij (D) \& \\ Huibert D. Mansvelder (D)
}

Correction to: Nature Communications https://doi.org/10.1038/s41467-019-13244-9, published online 21 November 2019.

The original version of this Article contained an error in the spelling of the author Wilma D.J. van de Berg, which was incorrectly given as Wilma D.J. van den Berg. This has now been corrected in both the PDF and HTML versions of the Article.

Published online: 04 February 2020

\begin{abstract}
(c) (i) Open Access This article is licensed under a Creative Commons Attribution 4.0 International License, which permits use, sharing, adaptation, distribution and reproduction in any medium or format, as long as you give appropriate credit to the original author(s) and the source, provide a link to the Creative Commons license, and indicate if changes were made. The images or other third party material in this article are included in the article's Creative Commons license, unless indicated otherwise in a credit line to the material. If material is not included in the article's Creative Commons license and your intended use is not permitted by statutory regulation or exceeds the permitted use, you will need to obtain permission directly from the copyright holder. To view a copy of this license, visit http://creativecommons.org/licenses/by/4.0/.
\end{abstract}

(C) The Author(s) 2020 